\title{
TRANSNATIONAL FATWAS ON JIHAD IN INDONESIA
}

\author{
Ansari \\ Shari'ah Faculty of State Institute for Islamic Studies, North Sumatra \\ Jl. Williem Iskandar Pasar V, Medan Estate, North Sumatra \\ E-mail: ansariyamamah@yahoo.com
}

\begin{abstract}
Abstrak: Fatwa Transnasional tentang Jihad di Indonesia. Fatwa memiliki kedudukan yang khusus dalam perkembangan hukum Islam. Kehadirannya dapat memberikan pengaruh terhadap sikap dan perilaku keagamaan seseorang. Meskipun fatwa merupakan produk ijtihad tetapi ia tetap dianggap sebagai aturan hukum yang harus dipatuhi terutama jika fatwa dikeluarkan oleh seorang ulama besar atau badan otoritas ulama yang memiliki pengaruh luas di masyarakat. Tulisan ini bertujuan untuk menelusuri pengaruh fatwa-fatwa transnasional tentang jihad yang mempengaruhi perilaku beragama masyarakat di Indonesia. Fatwa-fatwa tentang jihad mendorong sebagian umat Islam Indonesia untuk melakukan tindak kekerasan terhadap non Muslim. Gangguan terhadap agama menjadi salah satu alasan tindak kekerasan kepada mereka.
\end{abstract}

Kata kunci: fatwa, jihad, kekerasan, ulama

\begin{abstract}
Transnational Fatwas on Jihad in Indonesia. Fatwa has an important stake in Islamic legal development. Its presence is able to provide influences on person's religious attitude and behaviour. Although fatwa is a product of ijtihad, it's still considered as a rule which should be obeyed especially if it is pronounced by a great scholar or authorised body which has wide influence over the community. This paper will study thoroughly the transnational fatwas on jihad which had influenced people's religious attitude and behavior of many Indonesian Muslims. Fatwas on jihad motivated Indonesian Muslims to carry out violence towards non Muslims. The disturbance on religion became one of the reasons of violent actions towards them.
\end{abstract}

Keywords: fatwa, jihad, violence, scholar

\section{Introduction}

Fatwa, along with its multi dimensional aspects, is an important part of Islamic legal historiography and an exciting field study. Many books have been written on fatwa by Islamic scholars and legal experts on a national and global level.

If we focus on fatwas in Indonesia, we could see that fatwas have existed in Indonesian Muslim community since colonial periods. Fatwas were given by local Islamic scholar, transnational Islamic scholar, institutions, groups or organizations such as The Council of Indonesian Islamic Scholar (Majelis Ulama Indonesia, founded in 1975), Muhammadiyah (founded in 1926), Nahdlatul Ulama (founded in 1928), al-Washliyah (founded in 1930) and several other organizations in Indonesia.

For the case of Indonesia, fatwa and its social context are fascinating subjects of research. Besides functioning as legal regulations, fatwa also functions as a united

Received: 10th September 2013, reveised: 15th October 2013, accepted: 30th November 2013. factor for Indonesian Muslim community in numerous historical events such as the independence war against the colonial government, as well as a united factor for Indonesian development in the era of Old Order, New Order and Reformation.

From New Order to Reformation when fatwas are referred to the reference is usually to fatwas issued by The Council of Indonesian Islamic Scholar (MUI) which since its foundation has been the most authoritative body or institution to issue fatwas concerning Islamic legal issues in Indonesia. As such Atho Mudzhar in his research explicitly stated that the release of fatwa, for example MUI's fatwa in the years from 1975 to 1988, cannot escape the influence of socio-cultural dynamics of Indonesia. ${ }^{1}$

Another study which focuses on development of

\footnotetext{
${ }^{1}$ M. Atho Mudzhar, Fatwa-Fatwa Majelis Ulama Indonesia: Sebuah Studi tentang Pemikiran Hukum Islam di Indonesia 1975-1988, (Jakarta: INIS [Indonesian Netherlands Cooperation in Islamic Studies],1993), p. 5. This book is a translation of his dissertation, completed in McGill University, Canada, titled Fatwas of the Council of Indonesian Ulama: A Study of Islamic Legal Thought in Indonesia, 1975-1988.
} 
fatwas is by MB. Hooker, a professor at Australian National University. His book has been translated to Indonesian titled "Islam Madzhab Indonesia: FatwaFatwa dan Perubahan Sosial". Hooker's study was based on four important Islamic organizations as its main sources: Persis, NU, Muhammadiyah and MUI. It highlighted a number of fatwas issued from the 1920 s to 1930 s. Hooker was fascinated with the many similarities and differences which he found among the Islamic organizations researched. ${ }^{2}$

If we examine the current development of fatwas in Indonesia, we could see that they cannot be extricated from the context of historical scholarly relationship (thought) between Indonesian Islam and Middle Eastern Islam centred in Mecca, which in turn later would relate substantially to the development of fatwas in Egyptian Islam.

The robust relationship was indeed rooted in the scholarly networks of Indonesian and Middle Eastern scholar. Numerous Indonesian scholars who studied in the Middle East later returned to Indonesia and spread the Islamic mode of thought they obtained from the Middle East. Several illustrious figures who emerged from these networks are Nuruddin al-Raniri (d. 1068/1658), Abdurrauf al-Singkili (1024-1105/16151693) and Muhammad Yusuf al-Maqassari (10371111/1627-1699). ${ }^{3}$

Judging by the robustness of the relationship it was not surprising that lay Indonesian Muslims felt very close to Middle Eastern Muslims and their scholars. Often Indonesian Muslims would request fatwas for ritual, social, political and economic issues from the Middle Eastern scholars especially when Indonesia was under colonial rule.

Nico Kaptein described that many requests were made, which compilation could be gleaned from "Mubimmât al-Nafầis fî̀ Bayân al-'Illat al-Hadîts", reaching its zenith towards the end of the $19^{\text {th }}$ century with fatwa published by the most prestigious scholars (muftî) in Mecca which the most prolific scholars being Ahmad Dahlan, Syâfi'iyyah (followers of Syâfi'î) muftî (d. 1886). Not surprisingly Mecca was the centre of

2 MB. Hooker, Islam Madzhab Indonesia: Fatwa-Fatwa dan Perubahan Sosial, (South Jakarta: Teraju, 2003), p. 93.

${ }^{3}$ For further information about the scholarly networks between Indonesian and Middle Eastern scholars and their thought development, along with social, political, economic and religious development, see Azyumardi Azra, Jaringan Ulama Timur Tengah dan Kepulauan Nusantara Abad XVII dan XVIII: Akar Pembaharuan Islam Indonesia, (Jakarta: Prenada Media, 2004). authority for religious issues in traditional Indonesia. ${ }^{4}$

One of the most critical questions is despite the intimate scholarly relationships between Indonesian and Middle Eastern scholars, why does the Indonesian Muslim community still request fatwas from Middle Eastern scholars? Couldn't the local scholar issue fatwas to solve the legal problems of their community? One of the answers as given by Kaptein was that there was no uniformity of opinion among local muftî such that fatwa seekers sought the counsel of Meccan scholar deemed possessing higher authority. ${ }^{5}$ Another question is to what extent the fatwas of Middle Eastern scholar got implemented by the Indonesian Muslim community and how much impact do fatwas have towards the life of society?

The practice of giving fatwas seen from various perspectives and settings by an individual or a group of scholar in a particular state to another state is defined as transnational fatwa. Transnational fatwas are fatwas which travel outside its locus (between mustaftî and muftî from different states who may never even meet) based on requests which the author define as "fatwas following the law of supply and demand".

From the perspective of legal psychology, the acceptance, application and effectiveness of transnational fatwas has more traction than local fatwas. This was caused by the assumption that fatwa from scholar who reside internationally, in this case from the Middle East, was and still considered by most of Indonesian Muslims as more authoritative than fatwa from local scholar.

As time goes by, along with development of information technology, fatwas could be more easily communicated to society and more people know and subscribe to them.

More importantly, Umej Bathia noted that transnational fatwas accessible through cyberspace, what he dubbed as cyber-fatwas, carry greater potential to mobilize the global Muslim community (ummah) and sometimes are used as legitimation call for jihad by groups who consider themselves at war to defend their rights. The most current case in the global scene are fatwas of jihad by Osama bin Laden distributed through his infamous al-Qaeda networ, with the West

\footnotetext{
${ }^{4}$ For more on this matter see Nico J. G. Kaptein, The Voice of the Ulama: Fatwas and Religious Authority in Indonesia, (Archives de Sciences Sociales des Religions Arch. de Sc. Soc. Des Rel., 2004), p. 116.

${ }^{5}$ Nico J. G. Kaptein, The Voice of The Ulama: Fatwas and Religious Authority in Indonesia, p. 117.
} 
as targets of jihad. ${ }^{6}$

Contemporary transnational fatwa with Osama bin Laden as a central figure has changed the nature of traditional fatwa from being based on justice and social welfare to being based on threat and terror. When discussing about transnational fatwa, what has always come up is the question of jihad, the war between alQaeda (Osama bin Laden) with the United States and its allies.

Through fatwas of jihad, the al-Qaeda group, along with other groups of militant Muslims usually termed salafï, always proposed the notion of "clash" between the East (Islam) and West (Christian), not peace as insisted by humanity and religion. As such, it is not surprising that Western public (non Muslim) confused fatwa as a rigid or radical solution, such as declarations of war, death sentences (an example would be the fatwa issued by Ayatollah Khomeini upon Salman Rushdie, an British novelist who wrote a novel titled "The Satanic Verses') and violation of human rights. ${ }^{8}$

In the context of transnational fatwa for Indonesia today we could see the fatwa of Middle Eastern scholar on the obligation of Indonesian Muslim community to perform jihad in Ambon, Maluku, during the social unrest of 1999 , covered by many local and international media as interreligious unrest (Christians against Muslims) in the eastern part of Indonesia.

Along several lines of thinking on transnational fatwa

${ }^{6}$ Further see Umej Bathia, «Transnasional Fatwa and Radical Jihad», in IDSS Commentaries, no. 19, 2004, Nanyang Avenue Singapore: Institute of Defence and Startegic Studies. in , accessed on 31 May 2001.

Many experts categorize the Salafî groups as extreme and anti Western. Followers of these groups rejected idea and thoughts of Western origin based on the reason that Western thoughts are in opposition to Islamic doctrines. They claim that these idea come from the enemies of Islam especially Jews and Christians who intent to destroy Islam. One 'Western idea' rejected by the Salafî group is democracy such as election of leaders based on the majority votes which they considered a deviation of Islamic spirit. According to these Salafî groups, Islam teaches its followers to trust in God and when choosing leaders Muslims must choose based on values of faith and morality. The authority to lead the Islamic community must be chosen by an institution, abl al-ball wa al-'aqd, consisting of scholar and politician who always submit to the will of God Almighty. As a consequence, every Muslim must obey the leader (imâm) chosen by this institution. Giving power to a leader based on majority votes does not guarantee that a leader will not make mistake and will fight for the defense and prosperity of Muslims. The return to Alquran and sunah is the only way to solve all Muslim problems. See Ahmad Bunyan Wahib, Salafi Dawa Movement After The Dissolution of Laskar Jihad, (State Islamic University Sunan Kalijaga Yogyakarta), p. 22-23. See also Noorhaidi Hasan, Laskar Jihad: Islam, Militancy and the Quest for Identity in PostNew Order Indonesia, (Utrecht: Faculteit der Letteren en Internatonal Institute for the Study of Islam in the Modern World, 2005).

${ }^{8}$ Umej Bathia, Transnasional Fatwa and Radical Jihad, p. 3. and trends in the development (and thought) of Islamic legal systems, such as the acceptance of transnational fatwa by Indonesian Muslims, it becomes paramount to delve into its intricacies especially on the obligation of jihad. This is because the legal and formal strength of transnasional fatwa, especially concerning jihad, as legal guide for mustaftî, has increased as it penetrates state, cultural and borders, a phenomenon characterized in contemporary legal terminology as transnationalized law. ${ }^{9}$

\section{Typology of Fatwa \\ Traditional Fatwa}

With regards to fatwas in Indonesia, Nico Kaptein categorized fatwas into 3 types: traditional fatwa, modern fatwa dan collective fatwa. He defined traditional fatwa as fatwa issued by Meccan muftî in colonial times before the spread of Islamic reform idea to Indonesia (the Netherlands East Indies) in the early twentieth century inspired by Muhammad Abduh, Rasyid Ridha and others from Egypt. These traditional fatwas were collected in the volume "Muhimmât al-Nafầis fì Bayân al-'Illat al-Hadîts" which contained answers to a variety of ritual worship issues, inheritance regulations, marital regulations, food regulations, ethics, customs and relations with non Muslim government. As such the volume "Muhimmât al-Nafầi fî Bayân al-Illat alHadîts", according to Kaptein, can be considered as a representation of legal thoughts of traditional scholar then.

One example of traditional fatwa in "Muhimmât al-Nafầis fî Bayân al-Illat al-Hadîts" is the case in Palembang regarding the permissibility of performance of Friday prayers in two separate, nearby mosques of a city, so near that the voice of muadzdzins of both mosques can be heard at the same time. The answer given by the Syâf'iyyah muftî Sayyid Ahmad Dahlan was that

\footnotetext{
${ }^{9}$ Franz von Benda-Beckmann and Herbert von Benda-Beckmann elaborated that legal regulations are transnationalized when the regulations cross the original state borders to be implemented in the detination state. Technically, transnational law is also called as transplanted law, a particular state's legislation transplanted to another state to be used as legal regulation internally (internal use). Furthermore, Beckmann and Beckmann stated that "Transnational law may refer to the rules and institutions regulating (inter) action, relationship or wider networks that transcend national boundaries. Transnational law comprises all law that regulate actions or events that transcend national frontiers. It includes both civil and criminal aspects and may also involve states, individual, cooperations and other groups. See Franz von Benda-Beckmann dan Herbert von Benda-Beckmann, "Transnationalization of Law, Globalization and Legal Pluralism" in Sulistyowati Irianto (editor), Hukum yang Bergerak: Tinjauan Antropologi Hukum, (Jakarta: Yayasan Obor, 2009), p. 6-15.
} 
the prayers in both mosques are valid if the distance is sufficiently far such that it is difficult for someone who lives near one mosque to pray at the other. ${ }^{10}$

\section{Modern Fatwa}

The example of modern fatwa in this case are fatwas issued by Persatuan Islam (PERSIS) headed by Ahmad Hassan (1887-1958) and published in Persis Journal titled "Jurnal Pembela Islam" (Journal of the Defender of Islam) printed from 1929 to 1935 . The journal has a chapter titled "Soeal Djawab" (Question and Answer), containing a variety of answers to religious queries of the public. An example of fatwa is regarding the permissibility of drum calling before adzân to ready people for congregational prayers. The answer given by Ahmad Hassan was that drum calling never performed by the Prophet and his companions. The companions' numerous suggestions to call people for congregational prayer were vetoed by the Prophet. As such it is the obligations of Muslims to refuse all other attempts to call people to congregational prayer at the mosque except through adzân.

\section{Bukhârî and Muslim narrated a tradition:}

When the Muslims had entered Madina, they used to come together and wait for the [right time to start the] prayer without anyone making the call for it. On a certain day they began to speak about this and some said: "Let us use a drum like the drum of the Christians", while others said: "Let us use a horn like the horns of the Jews". Then 'Umar said: "Why don't you order a man to make the call for prayer?". For the Messenger of God has said: "O Bilâl, get up and make the call for prayer!" ${ }^{11}$

There are several reasons why fatwas issued by Ahmad Hasan through Persis are considered modern. Since the early twentieth century Indonesian Muslims have directed their fatwa request at scholar who resides in Indonesia, not scholar who resides in Mecca. In contrast to earlier fatwas, Ahmad Hassan's fatwas were issued neither in Arabic nor Malay Arabic (Jawi) letters which can be read only by those who can understand Arabic or at least familiar with its letters but the fatwas were issued in Latin alphabets such that more people could read it and they were even translated to local languages such as Sundanese ${ }^{12}$ and more remarkably,

10 Nico Kaptein, The Muhimmât al-Nafâis: a Bilingual Meccan Fatwa Collection for Indonesian Muslims from the End of the Nineteenth Century, prefaced and elaborated by Nico Kaptein, (Jakarta: INIS Materials 32, 1997), p. 111-112. The complete social history of the issuance of this fatwa can also be seen in Husni Rahiem, Sistem Otoritas dan Administrasi Islam: Studi tentang Pejabat Agama Masa Kesultanan dan Kolonial di Palembang, (Jakarta: Logos, 1998), p. 220-228.

${ }^{11}$ Nico J. G. Kaptein, The Voice of The Ulama: Fatwas and Religious Authority in Indonesia, p. 118-119.

${ }_{12}$ Akh Minhaji, Ahmad Hassan and Legal Reform in Indonesia, (Yogyakarta: Kurnia Kalam Semesta, 2001), p. 79-80. according to Kaptein, Ahmad Hassan used rational (ray) methodology in his ijtihads. Hassan emphasized that ijtihad is obligatory for a scholar, while lay people ('awwâm), eventhough they lack the knowledge of Arabic must know the reasons for the issuance of any particular fatwa by an scholar. For Ahmad Hassan, there are only two reasons to arrive at a fatwa, through ijtihad or ittibâ while taqlîd is not permissible. ${ }^{13}$

\section{Collective Fatwa}

In the first half of the twentieth century there was an important change to fatwa giving. Previously fatwa was issued by scholar as individual while in the new century fatwa was issued collectively or institutionally such as fatwa issued by Nahdlatul Ulama (NU) and Muhammadiyah which began to issue fatwa collectively since $1927 .{ }^{14}$

Another example of a collective fatwa was by alWashliyah, founded in 1930 in Medan during its fifth congress also in Medan, about the obligation of Muslims to fight the Dutch and its allies who attempted to take over Indonesia again in 1945 after the Indonesian Declaration of Idependence on 17 August 1945. In detail the fatwa contained two important matters, first being every Muslim has an obligation to fight to defend Indonesia's hard earned independence from the Dutch and second being every Muslim who died during the fight with intention of defending Islam died a martyr. The fatwa was also published in al-Washliyah magazine in 1941 which was banned from publication by the colonial government that same year due to its frequent provocation of society to resist the colonial government. Furthermore al-Washliyah released a policy to encourage every al-Washliyah member and their family to participate in defensive war through "Laskar Hizbullah" founded by al-Washliyah and in 1955 alWashliyah again released a policy encouraging every Muslim, especially al-Washliyah members, to choose Masjumi Party during the General Election of $1955 .{ }^{15}$

13 Nico J. G. Kaptein, The Voice of The Ulama: Fatwas and Religious Authority in Indonesia, p. 118-119. See also Akh Minhaji, Ahmad Hassan, p. 141.

${ }^{14}$ Nico J. G. Kaptein, The Voice of The Ulama: Fatwas and Religious Authority in Indonesia, p. 120. Further on the history and development of fatwa in NU tradition see Martin van Bruinessen, NU: Tradisi, Relasi-relasi Kuasa, Pencarian Wacana Baru, (Yogyakarta: LKIS, 1994), p. 220-234. The collection of fatwas issued by NU since 1926 till 1994 can be seen in Koleksi Fatwa NU dari Kongres Tahun 1926-1994, collected by Aziz Masyhuri in 1997.

15 Further on the fatwa and the chronology of its issuance see Ansari, Mission In Chriatianity and Islam: A Comparative Study of The Ways The Huria Kristen Batak Protestan (HKBP) and al-Washliyah Spread The Mission In North Sumatra (1930-1965), (Belanda: Leiden Univeristy, 1998), p. 75-76. 
Another example of collective fatwa as presented by Kaptein was the fatwa issued by Majelis Ulama Indonesia (MUI) which was founded based on the initiative of the then Indonesian President, Soeharto, to assemble scholar on a national level for coordination purpose with Muslim society. Aside from the initiative to involve scholar to find solutions to Muslim community problems related to the government, MUI has worked at the level of institution to issue many other fatwas relevant to the problems of Muslim community. MUI's fatwas were not only issued based on request by individuals or groups but also based on the request of the government to assist in the success of government programs, such as fatwa on the implementation of Planned Parenthood. ${ }^{16}$

It is astonishing to observe that a fatwa issued institutionally by MUI on behest of the government seemed to have quite a significant societal impact in the sense that it was felt as "binding", caused not only by religious reason but also by an "alignment" of interest between MUI and the government. Perhaps there has always been a legal syergy between MUI's fatwa and government's program in which the government "utilize" the MUI's fatwa to influence society to participate in the implementation of government's program.

\section{Fatwa as Changing Law Transplantation of Global Law}

A number of legal experts has stated, as mentioned by Beckmann and Beckmann, that a static law would not be able to keep up with the development of society in different times and places. As such, along with the development (globalisation) of society in all its forms, willing or not, directly or indirectly, law must develop along with time and locus be it regionally or transnationally, as can be seen by international treaty or agreement which is often defined as transnationalized law or globalized law. ${ }^{17}$

If we observe the development of law in the course of history, we cannot deny that law has found a transnational form such as law applied by colonial governments in its colony. As examples: English law applied in several Asian countries including Malaysia and Singapore; French law implemented in its colony in

${ }^{16}$ One fatwa requested by the government is a fatwa on Planned Parenthood issued by MUI in 1983. More details on this fatwa see M. Atho Mudzhar, Fatwa-Fatwa Majelis Ulama Indonesia, p. 126-132.

17 Further see Franz von Benda-Beckmann dan Herbert von Benda-Beckmann, "Transnationalization of Law, Globalization and Legal Pluralism" in Sulistyowati Irianto (editor), Hukum yang Bergerak: Tinjauan Antropologi Hukum, p. 6-15.
Africa including Morocco and Egypt; ${ }^{18}$ and Dutch law implemented in Indonesia. In theory, aside from many weaknesses, the implementation of this transnational law could be categorized as transplanted law.

A legal development which should attract academic attention is that many former colonial states have not been able to escape the influence and implementation of colonial law. Several states, Islamic or with a Muslim majority, have attemped to reformulate their law based on local wisdom or religious teachings but many have not been able to exit the cocoon of Western law. As a consequence there has been no other option but to have a mixed system, such as between Islamic and Civil Law, between Islamic and Common Law, and or between Civil and Traditional Law especially related to civil issues (al-ahwâl al-syakhshiyyah) ${ }^{19}$ such as the case for Indonesia.

However, if we scrutinize Indonesian legal cases, such as criminal and civil law, we will find two different forms of national legal system. In criminal cases, for example, the legal system used still refers to European legal system with the addition of Indonesian values and for civil cases the legal system used will be all three systems (Islamic Law, Civil Law and Customary Law). What is more interesting is all three systems are valid constitutionally. A legal subject can choose any law for their cases. For example, for specific civil cases, Muslims can choose between Islamic or European law (civil law) contained in BW. For non Muslims, they can only choose civil law. In several regions, after the implementation of regional autonomy such as Aceh and Banten, they have implemented Islamic legal system in the forms of Islamic Regional Law (PERDA Syariah).

Aside from the question of whether the existing legal pluralism is a bane or boon for the state, we need to observe that the diversity of legal systems used especially the Islamic one can contribute to confusing legal applications which might quite possibly be infiltrated by global or transnational legal thoughts. This because in Islam, there exists a principle which states that Islamic

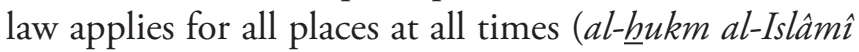

${ }^{18}$ See the interplay in Egypt between Islamic and European law, in this case French law in the form of Napoleon Code which gave birth to Egyptian Civil Codes. 'Abd al-Razzâq al-Sanhuri was the main proponent of the Egyptian Codes which formation was also influential to the formation of legal reforms in other states such as Iraq, Syria, Libya and Kuwait. Further see Muhammad Syahnan, Modernization of Islamic Law of Contract: A Study of 'Abd al-Razzâq al-Sanhuri's Mashâdir

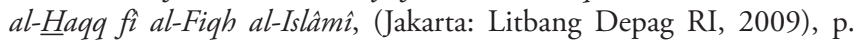
186-201.

${ }^{19}$ To know about the forms of legal systems applied in a variety of states, see Ade Maman Suherman, Pengantar Perbandingan Sistem Hukum, (Jakarta: Raja Grafindo Persada, 2004), p. 308-318. 
shâlih li kulli zamân wa makân).

As a logical consequence, Islamic law applied in Indonesia, on one hand cannot escape the influence of Islamic thoughts which have been proliferated by innumerable global scholar and adapted to local need. On the other hand the user of law (subjects of law) cannot avoid the temptation of requesting legal injunctions (fatwa) to transterritorial scholar.

\section{Transnational Fatwa}

If we observe from the vantage point of areal (territorial) limitation of fatwas, we could categorize fatwas into two, local and translocal fatwas. In this paper the term transnational fatwa which lately have been much utilized in academic circles such as used by Umej Bhatia in his paper titled "Transnasional Fatwa and Radical Jihad" published in 2004 by the Singapore based Institute of Defence and Strategic Studies Commentaries number 19.

Eventhough there has not been a clear definition of transnational fatwa, its roots can be traced as proposed by Umej Bathia who also named it cyber or satellite fatwa. Transnational fatwa is closely linked in its dissemination with the advance of information technology which have breached state territorial limit to have a massive impact in mobilizing Muslim masses. ${ }^{20}$

Different from transnational fatwa discussed by Umej Bathia, who in his writing focuses on jihad fatwas such as the ones issued by Moqtada al-Sadr (a Syiah scholar) about the obligation of Iraqis to fight against American forces in Iraq, transterritorial fatwa can be found in a collection of fatwas issued by Yûsuf al-Qaradhawî on a variety of Muslim social and religious topics, be it for those who live in the West or East. However in his book, Yûsuf al-Qaradhawî does not use the term "transnational fatwa", but "fatwa for the minority" (minority fikih) which can be interpreted as fatwas for Muslims who live among non Muslims. Yûsuf al-Qaradhawî emphasizes that his fatwas were issued to enable Muslims who live among non Muslims to practice Islamic injunctions and to apply Islamic law wherever they may be. As a support of his position such that his laws can be applied globally, Yûsuf al-Qaradhawî quoted the Alquran verse 115 of chapter al-Baqarah which means: "And Allah owns the East and West, so anywhere you face you will find God. Verily Allah's blessings are plenty and Allah is All-Knowing". ${ }^{21}$

\footnotetext{
${ }^{20}$ Further see Umej Bathia, Transnasional: Fatwa Fatwas and Religious Authority in Indonesia, p. 1.

${ }^{21}$ Yûsuf al-Qaradhawî, Fiqh Minoritas: Fatwa Kontemporer ter adap Kehidupan Kaum Muslimin di Tengah Masyarakat Non Muslim, pub. Adillah Obit, (Jakarta: Zikrul Hakim, 2004), p. 6.
}

Although Yûsuf al-Qaradhawî never describes his fatwa as transnational, it seems that he wishes to emphasize that fatwas in a transnational context can be applied by Muslims globally, be it by those who request the fatwas or those who are merely aware of the existence of such fatwas.

Furthermore, from an etymological viewpoint, the word transnational originates from English and is derived from two root words, trans and national. Trans means something that is present or moves from one place to another (on or from the other side off), ${ }^{22}$ while national means a nation or a group of societies which as a whole form the citizens of a state. ${ }^{23}$

As such, it can simply be said that a transnational fatwa is a fatwa issued by muftî of a state for (a group) of people in another state. The practice of issuing a fatwa from one state to another, seen from various perspectives and background, from an individual or a group of scholar $(m u f t i ̂)$ is called in this paper as transnational fatwa, fatwa which moves out of its locus (mustaftî and muftî are in different state or may never even meet) to travel globally upon request, fulfilling what can be called a demand and supply of law.

Based on legal psychology, acceptance, application and effectiveness of a transnational fatwa can be stronger and more powerful compared to local fatwas. This is at least because it is assumed that fatwas from foreign scholar, in this case from the Middle East, are perceived by some Indonesian Muslims to be more authoritative than fatwas from local scholar.

With the support of information technology, transnational fatwa can acquire elevated social political power for an individual or a group of society who obtained the fatwas. Several examples of social political impacts of transnational fatwa can be seen, for example, on fatwas issued by Ayatollah Khomeini on the permissibility of assasinating Salman Rushdie, writer of "The Satanic Verses", fatwa issued by Osama bin Laden through his al-Qaeda group on the obligation of Muslims to wage war against America and its allies and, especially for the case of Indonesia, fatwa issued by seven Middle Eastern scholars, upon the request of Indonesian Salafi groups under the umbrella of Laskar Jihad led by Ja'far Umar Thalib, on the obligation of Indonesian Muslims to perform jihad in Maluku. ${ }^{24}$

${ }^{22}$ The Oxford Paper Back Dictionary, (London: Oxford University Press, 1994), p. 853.

${ }^{23}$ The Oxford Paper Back Dictionary, p. 357.

${ }^{24}$ Further on the history of Laskar Jihad movement including the involvement of Laskar Jihad in the socio-religious conflict in Maluku and Sulawesi, see Noorhaidi Hasan, Laskar Jihad: Islam, Militansi dan 


\section{Transnational Fatwa on Jihad}

As elaborated above, transnational fatwa has become a contemporary phenomenon and a global issue assumed by non Muslims (Westerners) to be related to a number of violent acts committed by many Muslim movements in the East against the West especially in its hegemonic cultural form seen by many Muslims as something which needs to be urgently overthrown.

On one hand, fatwa as assumed by the West as identical with violence or resistance do have traction in reality evidenced by the issuance of transnational fatwas related to jihad movements to wage "Eastern holy war" against "Western hegemony." On the other hand Muslim transnational movement always campaign for global war against those perceived as Muslim enemies for the upholding of Islam as a universal religion free from state territorial limits and against Western neo colonial hegemony in Muslim states be it politically, economically, socially and culturally, at least according to Muslim radical groups.

The hostility between these two groups, aside from the socio-political reasons mentioned above, was surely influenced by ideology including systems of belief and breadth of thought (weltanschoung), between sociological based West and theological based East, which may never be united, as pithyly expressed by the proverb "East is East and West is West, never the twain shall met". In other words, the West always evaluates based on humanistic gain and loss (socio-humanitarian perspectives) while the East based on right and wrong or Islam and non-Islam (theological-normative dimension).

As such, Islamic transnational movement such as Laskar Jihad in Indonesia, always seek legal legitimation for their movement by requesting issuance of jihad fatwas from scholar they consider authoritative and supportive of their movement.

In this paper the author intentionally employ the jihad fatwas issued by seven Middle Eastern scholars used by Laskar Jihad to legitimate their "holy war" in Maluku, in which they consider Muslims in Maluku to be oppressed. Based on the fatwas Laskar Jihad mobilized the Muslim masses to join the holy war in Maluku. $^{25}$

With the fatwas Ja'far Umar Thalib forcefully stated

Pencarian Identitas di Indonesia Pasca Orde Baru, (Jakarta dan Leiden: LP3ES dan KITLV, 2008). See also Jamhari and Jajang Jahroni, Gerakan Salafi Radikal di Indonesia, (Jakarta: Raja Granfindo Perkasa, 2004).

${ }_{25}$ Noorhaidi Hasan, based on the interview with Muhammad Umar as-Sewed, elaborated that the Salafîs in Maluku as part of the transnational dakwah community, which in Indonesia represented by that the Maluku conflict was an arena of holy war against Christian enemies attack on Islam. Ja'far stressed that joining the war is an obligation for Muslims as part of obedience of God's command. Ja'far quoted Ibn Taymiyya “... when enemies wish to launch an attack against Muslims, countering the attack is obligatory for all Muslims under attack. Also, it is obligatory for other Muslims not under attack to support their fellow Muslims". ${ }^{26}$

As such, it cannot be denied that the issuance of fatwa, on one hand, provide strong legitimation for Salafi groups, in this case Laskar Jihad, to mobilize volunteers for dangerous and violent collective action under the leadership of Ja'far Umar Thalib. On the other hand, this legitimation is surely important for Salafî groups to reach internal agreement which could be a solid foundation for them to go beyond their fundamental beliefs to maintain consistency of a non political proselytization strategy, considering there are some Indonesian salafî groups against their jihad pronouncement. Groups against the mobilization of jihad volunteers hold that the main task of Salafî groups is consistent proselytization, not involvement in politics. They even claimed the jihad pronouncements of Laskar Jihad invalid and fatwas issued were forged. ${ }^{27}$

Aside from some Salafî groups who contested the jihad movement to Maluku, Laskar Jihad under the leaderhip of Ja'far Umar Thalib, armed with transnational fatwas from seven Middle Eastern scholars has managed to arouse the spirit of Salafî groups to perform jihad in Maluku which they claimed as defending the rights of Muslims and the religion of Allah.

Laskar Jihad, requested fatwa from a number of authoritative Middle Eastern scholars who are all related to Bin Baz, the former leader of the Head of Senior Scholar Council of Saudi Arabia. Among the scholar whose fatwas was requested was 'Abd al-Razzâq ibn 'Abd al-Muhsin al-'Abbâd, Muqbil ibn Hadi al-Wadi'î, Rabî̀ ibn Hâdî al-Madkhalî, Shâlih al-Suhaymî, Ahmad Yahyâ ibn Muhammad al-Najm and Wâhid al-Jâbirî. Those fatwas were requested by the Laskar Jihad Salafî movement through facsimiles and telephone to their cadres studying in the Middle East who then forwarded the questions to the (muftî). As they seemed too reluctant to issue a fatwa, Ja'far Umar Thalib and Muhammad Umar as-Sewed visited them in person to persuade and provide additional information. The scholar relented and issued a fatwa, which in essence obligated Indonesian Muslims to perform jihad in Maluku. Further see Noorhaidi Hasan, Laskar Jihad: Islam, Militansi, dan Pencarian Identitas di Indonesia Pasca Orde Baru, p. 166-167.

${ }^{26}$ Noorhaidi Hasan, Laskar Jihad: Islam, Militansi dan Pencarian Identitas di Indonesia Pasca Orde Baru, p. 169. See also Noorhaidi Hasan, "Between Transnastional Interest and Domestic Politics: Understanding Middle Eastern Fatwas on Jihad in the Moluccas", in Nico Kaptein and Michael Laffan, ed., Islamic Law and Society, January 2005, p. 73-92.

${ }^{27}$ Noorhaidi Hasan, Laskar Jihad: Islam, Militansi dan Pencarian Identitas di Indonesia Pasca Orde Baru, p. 169-170. 
To delve into the contents of the fatwas, in this paper, the writer includes several fatwas which translation the author quotes from the book "Gerakan Salafi Radikal di Indonesia". First, fatwa issued by Syaykh Rabî ibn Hâdî al-Madkhalî, an expert scholar in hadis residing in Mecca "It is obligatory upon every Muslim to carry out jihad in Maluku in order to defend the Muslims from attacks of the Christians. And this jihad is seen as defending the religion of Islam from the attack of Christians".

Second, fatwa issued by Syaykh Muqbil ibn Hâdî al-Wadi $\hat{\imath}$, a famous scholar also expert in hadis residing in Yaman:

It is obligatory upon every Indonesian Muslims to carry out jihad defending their brothers in Maluku and obligatory as a collective upon every Muslims outside Indonesia, noting that: (1) Muslims should possess the ability to carry out jihad against the non Muslims. (2) The effort of jihad must not cause conflicts among Muslims. (3) The ability possessed by Muslims to carry out jihad must not depend on the strength of non Muslims but depend on the strength of the Muslims themselves putting their trust in God. (4) The jihad carried out must be based on Sunna (translator: that is based on the creed of abl alsunnah wa al-Jamâa ah) and not based on sectarian divisions. (5) The jihad carried out must not turn Muslim away from their obligation to learn about Islam. (6) The jihad carried out must not give the impression that Muslims are fighting for political positions or material gain. But Muslims must be prepared physically and spiritually to carry out jihad merely for the sake of Allah to stop the encroachment of christians upon Muslims.

The fatwa issued by Syaykh Rabî̀ ibn Hâdî alMadkhalî, an abl al-sunnah wa al-Jamâah scholar residing in Medina:

Three actions you conduct to make feasible jihad in Ambon are correct actions. The government's prohibition against your defending of your fellow Muslims should not be obeyed. Because the Prophet Muhammad (peace be upon him) has commanded: "There should be no obedience towards creatures if the obedience causes disobedience towards the Creator". ${ }^{28}$

\section{Ideology and Networks of Transnational Radical Movements in Indonesia}

Discussing about transnational militant Muslim movements (transnational Muslim hardliner groups) around the world, there is no doubt that contemporary Salafî dakwah movements, which has slowly evolved since the appearance of al-Jamâah al-Salafiyyah in

\footnotetext{
${ }^{28}$ To see further the fatwa of other Middle Eastern scholars, see Jamhari dan Jajang Jahroni, Gerakan Salafi Radikal di Indonesia, p. 100-104.
}

Saudi Arabia in the 1960s, has contributed greatly as a representation of the most puritanical Muslim sects ${ }^{29}$ mostly influenced by Wahabi thoughts (Wahabism) developed by Muhammad ibn 'Abd al-Wahhâb (170319792), who took his inspiration from the thoughts of Taqî al-Dîn Ahmad ibn Taymiyyah (1263-1328), a follower of Hanbalism, the strictest school of thought of the four widely accepted (mu'tabarah) school of thoughts. In its development, contemporary Salafîs were influenced to a large extent of the reformist-modernist thoughts of Jamaludin al-Afghani (1838-1935), Muhammad Abduh (1849-1905) and Muhammad Rasyid Ridha (1865-1935) who offered plans to return to the times of Muslim glory through the utmost use of rationality (ijtihâd) and the adoption of modern development. As the development of contemporary Salafî movements went along the rise of Muslim political awareness against Western neo colonization as a result there appeared a strong desire to recover modern development believed to be stolen by the West from Muslims. ${ }^{30}$ Unfortunately, the failure of Muslims to recover the modern development, along with the internal failure of Muslims to maintain its own culture against Western invasion, has distorted the spirit of the Salafî groups from efforts of recovering modern progress to ideological antipathy, which in turn made the Salafi movement more extreme and radical.

Thus, the Salafî not only made the West as enemy to be fought against but also consider any actions not practiced by the earliest generations (al-salaf al-shâlih) outside the pale of Islam.

If we delve into the ideology of the Salafî movement we could discern several differences between them, be it religious ${ }^{31}$ or social and political, which turn them Radical as opposed to Conservative. Among these differences are: first, they always exhibit the mentality of "holy war" when facing a different ideology (Islam-

\footnotetext{
${ }^{29}$ Khaled M. Abou el-Fadl has written that the historical pattern of puritanical Salafî groups began during the Wahabi period. In his book Khaled Abou el-Fadl provided several elaborations of the puritanical groups understanding as well as their rigid and extreme applications including in the context of Muslim and non Muslims Relations (EastWest), matters of jihad, women and human rights. Further see Khaled Abou el-Fadl, Selamatkan Islam dari Muslim Puritan, Helmi Mustafa (tr.), (Jakarta: Serambi Ilmu Semesta, 2006).

${ }^{30}$ Further see Noorhaidi Hasan, Laskar Jihad: Islam, Militansi, dan Pencarian Identitas di Indonesia Pasca Orde Baru, p. 34-35.

31 An understanding of scriptural nature, which is a textual understanding without contextual consideration. This understanding will give rise to fanatical and militant attitude which in the end may lead personal truth claim. In other words, an understanding which severes the relationship between the author, the reader and the social context surrounding it. Further see Khaled Abo el-Fadhl, Atas Nama Tuhan: Dari Fikih Otoriter ke Fikih Otoritatif, R. Cecep Lukman Yosin (tr.), (Jakarta: Serambi Ilmu Semesta, 2003).
} 
Christian/East-West). This could be seen from their view that the current Western hegemony, as a "new form of colonialism", needs to be eliminated. Also, the idea of Western conspiracy against Islam and the Muslim world is popular among this crowd and as such they propagate a strong anti Western feeling to the extent of rejection of all idea originating from the West although this is actually in opposition to the teachings of Jamaludin al-Afghani, Muhammad Abduh and others who they consider as salafiyyah reference.

Second, the enforcement of Islamic law often struggled for by Muslim radicals is no longer considered as an alternative path but an "imperative". In other words, there is no other way they consider as valid to form an Islamic community which obeys God's command except by making Islam as the foundation of religious, social and political life.

Third, they are exist a tendency to contest the government and its established systems, which they consider illegitimate. This is because of lack of government's effort to alleviate social ills they identify as immoral and irreligious. As such some of these groups no longer trust government legal institutions to cure those ills and took matters to their own hand without consideration of 'publicness' of the public square.

Fourth, the spirit to uphold religion as the truth of God's teaching on earth through the way of "jihad" earns its own place of honor. Jihad efforts especially through arms struggle is deemed as the most holy act.

Fifth, the worsening Muslim-Jewish relationship in the Palestine area, as well as the worsening relationship between Muslims and Christians in various region including Indonesia due to the contentious issue of christianization, has been influential to radicalize some militant Muslim groups, ${ }^{32}$ especially radical Salafî ${ }^{33}$ as is the case in Indonesia.

Militant Muslim movement (Muslim hardliners) in Indonesia, in this case represented by the Salafî movement with its various groups, lately have resurfaced to become a most interesting social phenomena. This is because these militant groups not only show themselves

${ }^{32}$ Further see Jamhari dan Jajang Jahroni, Gerakan Salafi Radikal di Indonesia, (Jakarta: Raja Grafindo Persada, 2004).

33 The famous term for this is Jihadi Salafis, but the author separates the term Jihadi Salafîs with Radical Salafis, at least in the case of Indonesia. Radical Salafîs can be linked more to the Salafî groups existing in Indonesia, such as Laskar Jihad, Front Pembela Islam, Majelis Mujahidin Indonesia and Hizbut Tahrir Indonesia, in which their movement is always open in nature and mass-organized. While the Jihadi Salafis is more global in nature and always secretive in the course in their actions such as the plotting and executing bomb terrors by Amrozi and Imam Samudra. According to Solahudin, a researcher to be concerned with purification of religious life but also with the purification of social and political life.

Their appearance in the social and political arena surely does not occur in a sudden but with strong reasons and backings such that they feel that they have obtained strong legitimation to perform stern acts, through rigorous and radical means, to uphold amar ma'rûf and nahy munkar, a goal which they most cherish.

In addition, the appearance of these Muslim hardliners in Indonesia cannot escape its roots of history, network and ideology of struggle, be it nationally, along with national political uphevals and transnationally as a reaction to various actions in the course of Muslim struggle against Western hegemony in the form of Christian, capitalist, materialist and liberalist ideology.

If we see from the national point of view, history has recorded the desire of some of Muslim community who formed a rebellion collective in the Movement of Gerakan DI/TII to form an Islamic State (Dawlah Islamiyyah) out of the Indonesian state. ${ }^{34}$ This idea of

and a reporter who presented his paper to the Salihara Community on 12 May 2011, several of these groups were borne out of the Salafî or Neo Wahabi teaching which beliefs are in principle held by both Salafî and Jihadi Salafî groups which both try to revive what they consider as the salaf shâli $\underline{h}$ understanding of Islam, pure and undistorted Islam. They also possess a similar undersanding of fiqh for worship and taubî̀d, which is taubîd rubûbiyyah, taubîd ulûhiyyah and taubî̀ asmâ wa sifatt. What differentiates them is Jihadi Salafis possess a more specific understanding of jihad and tauhîhd hâakimiyyah. Different from the Salafî groups mentioned above, there are four main doctrines of Jihadi Salafîs, which are: (1) The concept of qitâl fî̀ sabîl Allâh, meaning syar'î jihad or physical war with no other interpretation possible. (2) The law on jihad which in the beginning was fardh kifâyah becomes fardl 'ayn because Muslim lands have been occupied by non Muslims, be it ajnabî non Muslims (foreign non Muslims) or mahalî non Muslims (local non Muslims) such as murtad rulers who preside over Muslim countries. As such all Muslims are obligated to chase these non Muslims out of the Muslim area. (3) Irhâbiyyah (terrorism) allowed by the syariat of jihad. One of the forms of permissible terror is killing civilians previously impermissible to kill such as children, women, old people or priests. These innocent people whose blood are sacred can be killed if they help the non-Muslims fight the Muslims including in killing civilians in the context of qishâsh or revenge. (4) Tauhîd hâkimiyyah, the concept which considers that political sovereignty is entirely in the hands of God. This view is in opposition to the view of democracy which put people's sovereignty as the highest political sovereignty. The realization of God's sovereignty manifest in the application of Islamic syariah bounding social and political life. The rejection to Islamic syariah is equivalent to God's sovereignty. As a consequence, any rejectors will be considered outside the pale of Islam even if he has recited the syahadah and perform prayers. For more see Solahuddin, Sejarah, Faham dan Gerakan Jihad di Indonesia, accessed through google on 22th June 2011, with the keywords "fatwa tentang jihad di Indonesia".

${ }^{34}$ To understand the DI/TII movement comprehensively, see Cis van Dijk, Rebellion under the Banner of Islam: The Darul Islam in Indonesia, (The Hague: Martinus Nijhoff, 1981). Also see Hiroko Horikoshi, "The Darul Islam Movement of West Java: An Experience in the Historical Process," in the journal Indonesia, vol. 20 (Jakarta: Oktober 1975) and Jajang Jahroni, "Islamic Contemporary Movement 
DI/TII movement which later become NII in the 1970s has resurfaced in the movement of Majelis Mujahidin Indonesia. ${ }^{35}$

The case is similar with other transnasional Salafî hardliner groups, whose members consist of male youths with long robe (jalabiyah), head covering (imâmah), long pants (isbâl), and long beard (lihyah) and female youths with veil (niqôb) and black clothing which covers the entire body, in the public square of many cities such as in Jogjakarta, Solo, Semarang, Bandung, Jakarta, Makassar and Medan.

One of the most phenomenal Salafi groups in Indonesia is the Laskar Jihad group formed by Ja'far Umar Thalib (of Hadrami descent born in Malang in 1961) $)^{36}$ and several other well-known Salafî figures such as Muhammad Umar as-Sewed and Ayip Syafruddin. Laskar Jihad, which in the beginning was a special division of the Forum for Communication between Members of abl al-sunnah wa al-Jamâah (Forum Komunikasi Ahli Sunnah Wal-Jamaah - FKAWJ), was founded in Jogjkarta on 30 January 2000, through a grand assembly of FKAWJ in Kridosono Yogyakarta. The establishment of Laskar Jihad cannot escape the riot events in Ambon, Maluku, which have been understood by most people as religious and social conflicts between Muslims and Christians started on 19 Januari 1999 which is also the day of Eid of 1999 (1 Syawal 1419 H). ${ }^{37}$

Notwithstanding the various interpretation of forms and nature of social conflict, which in the short term has produced many victims, ${ }^{38}$ Laskar Jihad view that

in Indonesia”, dalam jurnal Refleksi, vol. II (1), (Jakarta: UIN Jakarta, 2001).

${ }^{35}$ Interesting to compare further the fighting methods of Majelis Mujahidin with the DI/TII movement first conducted attacks sporadically and possess transnational network while DI/TII was local and political in nature. On the methods conducted by the Majelis Mujahidin group in their fight see Muhamam Asfar (ed.), Islam Lunak Islam Radikal: Pesantren, Terorisme dan Bom Bali, (Surabaya: PuSDeHAM dan JP Press Surabaya, 2003).

${ }^{36}$ For more on the personal history including the formal and non formal education background of Ja>far Umar Thalib see Jamhari dan Jajang Jahroni, Gerakan Salafi Radikal di Indonesia, p. 90-96.

${ }^{37}$ Jamhari dan Jajang Jahroni, Gerakan Salafi Radikal di Indonesia, p. 85.

${ }^{38}$ According to the government report as conveyed by the Head of Indonesian Police, then, Letjen Roesmanhadi, for three days of conflict (until 21 January 1999) the riot in Ambon has claimed victims as follow: 22 people dead, 102 heavily wounded and 45 with minor injury. 107 houses, 7 places of worship, 2 traditional markets, 2 banks, 33 shops, 12 kiosks, 22 cars, 25 motorcycles and 216 motorized pedicabs. Further see Mohammad Shoelhi, Laskar Jihad: Kambing Hitam Konflik Maluku, (Jakarta: Puzam, 2002), p. 12. Eventhough there was no offical report on the number of victims resulting from the 5 year conflict, according to government estimate as written by A. C. Manullang, the conflict shed more than 2000 lives. Further see A. C. the Muslims in Ambon are under duress, facing the threat of genocide and as such it is the responsibility of the Muslim community to perform jihad against the Christians. As a result, on the date mentioned above, Laskar Jihad was founded to help Muslims in Ambon fight the Christians.

From the point of view of network and funding source, the Salafi movements in Indonesia, beside having national networks also possess strong relationships with transnational Salafî movements, be it in the form of socio-religious network ${ }^{39}$ or in the form of institution such as can be visibly seen in the relationship between Majelis Mujahidin Indonesia, various Jamâ ah Islâmiyah groups in South East Asia and even al-Qaeda. ${ }^{40}$ The same strong relationship can be seen between Laskar Jihad who possess strong relationship with Jemaah Salafiyyahs in various Middle Eastern countries and several South East Asian and Central Asian countries. These relationships also exist with several universities in Saudi Arabia such as the University of Imâm Muhammad Ibn Sa'ûd and Madinah Islamic University, ${ }^{41}$ and in Indonesia with Jakarta-based "Lembaga Ilmu Pengetahuan Islam dan Bahasa Arab" (LIPIA) owned by Saudi Arabia government.

It is interesting to observe that Laskar Jihad not only possess strong relationship with several Middle Eastern universities, especially in Saudi Arabia, but also with the Salafî ulamas (muftî) residing there. This could be seen from the request of opinions by Laskar Jihad to the muftîs who in the end issued fatwa of jihad on the conflict in Ambon, Maluku, in 2000, which made it compulsory for Indonesian Muslims to perform jihad there. These fatwas were the scholarly weapon of Laskar Jihad to mobilize thousands of Indonesian Salafis to participate in the Ambon conflict.

\section{Mashlahah as The Main Purpose of Fatwa}

A question remains: why Salafî groups, such as Front Pembela Islam, Laskar Jihad and Laskar Mujahidin could easily fall into violent acts?

Seen from a religious perspective, according to Francois Houtart, ${ }^{42}$ there are at least three kinds of

\footnotetext{
Manullang, Menguak Tabu Intelijen, Terror, Motif dan Rezim, (Jakarta: Panta Rhei, 2001).

${ }^{39}$ Jamhari dan Jajang Jahroni, Gerakan Salafi Radikal di Indonesia, p. 78.

${ }^{40}$ Noorhaidi Hasan, Laskar Jihad: Islam, Militansi, dan Pencarian Identitas di Indonesia Pasca Orde Baru, p. 13.

${ }^{41}$ With regards to the institutional network of the Salafî movement including Laskar Jihad see Noorhaidi Hasan, Laskar Jihad: Islam, Militansi, dan Pencarian Identitas di Indonesia Pasca Orde Baru, p. 34-35.

${ }_{42}$ As quoted by Muhammad Asfar, Islam Lunak Islam Radikal:
} 
explanations. First, religion is always interpreted as a theological framework which bounds social relationships (ideological function). This kind of theological interpretation, as has been commented by Amin Abdullah, ${ }^{43}$ has in its basic conviction of possessing absolute truth without bothering to delve into rational intepretation of religious texts. According to this interpretation every relationship between groups which form a society should have as its source the will of God, which should be based on the rule of God, and anything outside this rule should be refused and rejected. As a consequence there would be created personal or group truth claims which in turn lead to the denial of existence of other groups possessing their own truth claim. This kind of dictatorship of theological interpretation in a social and humanitarian context will give birth to an exclusive attitute which creates division between the right group and wrong group or in religious parlance between the faithful group and unfaithful group. In turn, it becomes ironical that religion which should be a source of peace and ethics has become instead source of strife and violence.

Second, religion is turned into a source of identity which can provide status, stability and a way of thinking such that people coming from the same background can differ due to religious difference.

Third, religion as a legitimation of social relationship which is visible in the creation of some public policies in which government collaborates with religious figures. This could be an excuse for government oppositions to rail against both government and the religious figures should the policies be deemed against God's law. ${ }^{44}$

Religious-based violence based on fatwa is a common occurence in Indonesia. Examples would be the fatwa issued Forum Ulama Umat Indonesia (FUUI) on the death sentence of Ulil Abshar Abdalla, the coordinator of Jaringan Islam Liberal (JIL), because he is deemed an apostate, ${ }^{45}$ the fatwa issued by Majelis Ulama Indonesia (MUI) on the banning of Ahmadiyah and the most

Pesantren, Terorisme dan Bom Bali, p. 54-55.

43 Amin Abdullah stated that the fundamental structure of theological thought usually related to character, which are: (1) The tendency to put primacy over own group. (2) Personal involvement and with the theological thought. (3) The exposition of feeling and thought using 'doer' not 'observer' language. The unification of these three characteristics in a person or a group provides a large motivation for the creation of theological enclaves which tends to be exclusive, emotional and rigid. Further see Amin Abdullah, Studi Agama: Normativitas atau Historisitas?, (Yogyakarta: Pustaka Pelajar, 1996), p. 14.

${ }^{4}$ Haryatmoko, Etika Politik dan Kekuasaan, (Jakarta: Kompas, 2004), p. 64. Compare with Muhammad Asfar, Islam Lunak Islam Radikal: Pesantren, Terorisme dan Bom Bali, p. 55.

${ }^{45}$ Ulil Abshar Abdalla et. al., Islam Liberal dan Fundamental; Sebuah Pertarungan Wacana, (Yogyakarta: eLSAQ Press, 2003), p. 15. phenomenal the fatwa by 7 Middle Eastern ulama on the obligation of performing jihad in Ambon as elaborated above. These fatwas has been proven to cause more harm than benefit due to the violence actions they inspire.

As such a fatwa should not be accepted if it results in harm as this contradicts the basic philosophy for fatwa which is the provision of alternative solution made in harmony with local wisdom to bring peace, order and justice for a community. This is clearly stated by Imâm al-Syâthibî in that a mujtahid (muftî) cannot apply a legal injunction derived from the Alquran and sunah as it is but a mujtahid must consider the context of the community in which the fatwa is issued as the community is both the subject and object of the fatwa. ${ }^{46}$

The theory of mashla $\underline{a} a t$ (istishlâh) often used in contemporary ijtihad when checked against the concept of dhawâbith al-mashlabah, as has been stated by Ramadan al-Bûthî, must fulfill five criteria: prioritising the goals of syariat, not against the Alquran, not against the sunah, not against the principle of qiyâs and be made to bring mashlahah. ${ }^{47} \mathrm{~A}$ fatwa, to the author's mind, should produce mashla $\underline{\text { hah in }}$ accordance with qawẩid al-uqûll al-ijtimâizyyah. ${ }^{48}$

\section{Closing Remarks}

Viewed from the point of view of social history of fatwa development in Indonesia, transnational fatwa is not a new phenomenon. In the colonial times, fatwa had been imported to Indonesia and applied by the Indonesian Muslim community then. These transnational fatwas entered Indonesia through the networks of Indonesian and Middle Eastern scholar especially those who reside in Mecca, as Mecca was considered the most authoritative territory to refer all religious matters to. From the point of view of content (substance), the transnational fatwas issued then broadly revolved around issues of worship, civil matters (al-ahwâl al-syakhshiyyah) and socio-religious life.

Different from the colonial transnational fatwa, contemporary transnational revolves more around

${ }^{46}$ Abû Ishâa al-Syâthibî, al-Muwâfaqât, (Beirut: Dâr al-Kutub al'Ilmiyyah, 2002), p. 76-77.

${ }^{47}$ Muhammad Sa'îd Ramadhân al-Bûthî, Dhawâbith al-Mashlahah fì al-Syarîah Al-Islamiyyah, (Beirut: Muassasah al-Risâlah, 1986), p. 142 .

${ }^{48}$ The idea of qawâid al-'uqûl al-ijtimâizyah is an approach in the methodology of legal arrangement in the contemporary Ushûl al-Fiqh study and this idea has been published in World Journal of Islamic History and Civilization (IDOSI Publication). 
politics and ideology as a result of a perceived clash between the Muslim and Western world, be it in the field of economics, politics, social and cultural.

As in global competitions Muslims are always on the losing side, due to their frequent inabilities to compete rationally and scientifically, that is based on science and technology, there appeared a number of movements seeking religious legitimation to fight against the West which then becomes enemies in the fields mentioned above.

The religious legitimation is often accompanied by the authority of fatwas in its transnational form. These fatwas are used by puritanical and ideological Salafî groups, in Indonesia represented by Laskar Jihad, to support their war against the West and against all ideologies they deem as being outside the pale of pure Islam.

In their use of these transnational fatwas, these Salafîs always speak in the context of jihad (which they understand to be a war against "global crime"). As such fatwas have gained a new and negative recognition by some Westerners who equate fatwa with legitimation of war, violence and violations of human rights. []

\section{Bibliography}

Abdalla, Ulil Abshar, et. al., Islam Liberaldan Fundamental: Sebuah Pertarungan Wacana, Yogyakarta: eLSAQ Press, 2003.

Abdullah, Amin, Studi Agama: Normativitas atau Historisitas?, Yogyakarta: Pustaka Pelajar, 1996.

Ansari, Mission in Chriatianity and Islam: A Comparative Study of The Ways The Huria Kristen Batak Protestan (HKBP) and al-Washliyah Spread The Mission In North Sumatra (1930-1965), Thesis, Belanda: Leiden Univeristy, 1998.

Asfar, Muhamm (ed.), Islam Lunak Islam Radikal: Pesantren, Terorisme dan Bom Bali, Surabaya: PuSDeHAM and JP Press Surabaya, 2003.

Azra, Azyumardi, Jaringan Ulama Timur Tengah dan Kepulauan Nusantara Abad XVII dan XVIII: Akar Pembaharuan Islam Indonesia, Jakarta: Prenada Media, 2004.

Bathia, Umej, "Transnasional Fatwa and Radical Jihad”, in IDSS Commentaries, number 19 year 2004.

Benda-Beckmann, Franz von dan Herbert von Benda-Beckmann, "Transnationalization of Law, Globalization and Legal Pluralism dalam Sulistyowati Irianto (ed.), Hukum yang Bergerak: Tinjauan Antropologi Hukum, Jakarta: Yayasan Obor 2009.

Bûthî, al-, Muhammad Sâîd Ramadhân, Dhawâbit
al-Mashlahah fî Syarîah Al-Islâmiyyah, Beirut: Muassasah al-Risâlah, 1986.

El-Fadhl, Khaled Abou, Atas Nama Tuhan: Dari Fikih Otoriter ke Fikih Otoritatif, translated by R. Cecep Lukman Yosin, Jakarta: Serambi Ilmu Semesta, 2003.

Haryatmoko, Etika Politik dan Kekuasaan, Jakarta: Kompas, 2004.

Hasan, Noorhaidi, "Between Transnastional Interest and Domestic Politics: Understanding Middle Eastern Fatwas on Jihad in the Moluccas", dalam Nico Kaptein dan Michael Laffan (ed.) Islamic Law and Society, January 2005.

Hooker, MB., Islam Madzhab Indonesia: Fatwa-Fatwa dan Perubahan Sosial, Jakarta: Teraju, 2003.

Jahroni, Jajang, "Islamic Contemporary Movement in Indonesia”, in the journal Refleksi, vol. II (1), Jakarta, 2001.

Jamhari amd Jajang Jahroni, Gerakan Salafi Radikal di Indonesia, Jakarta: Raja Granfindo Perkasa, 2004.

Kaptein, Nico J. G., The Voice of the Ulama: Fatwas and Religious Authority in Indonesia, (Archives de Sciences Sociales des Religions Arch. de Sc. Soc. Des Rel.,) 2004.

Manullang, A. C., Menguak Tabu Intelijen, Terror, Motif dan Rezim, Jakarta: Panta Rhei, 2001.

Minhaji, Akh., Ahmad Hassan and Legal Reform in Indonesia, Yogyakarta: Kurnia Kalam Semesta, 2001.

Mudzhar, M. Atho, Fatwa-Fatwa Majelis Ulama Indonesia: Sebuah Studi tentang Pemikiran Hukum Islam di Indonesia 1975-1988, Jakarta: Indonesian Netherlands Cooperation in Islamic Studies, 1993.

Qaradhawî, Yûsuf, Fiqh Minoritas: Fatwa Kontemporer terhadap Kehidupan Kaum Muslimin di Tengah Masyarakat Non Muslim, translated by Adillah Obit, Jakarta: Zikrul Hakim, 2004.

Rahiem, Husni, Sistem Otoritas dan Administrasi Islam: Studi tentang Pejabat Agama Masa Kesultanan dan Kolonial di Palembang, Jakarta: Logos, 1998.

Shoelhi, Mohammad, Laskar Jihad: Kambing Hitam Konflik Maluku, Jakarta: Puzam, 2002.

Solahuddin, Sejarah, Faham dan Gerakan Jihad di Indonesia, accessed through Google google on 22 June 2011.

Van Dijk, Cis, Rebellion Under the Banner of Islam: The Darul Islam in Indonesia, The Hague: Martinus Nijhoff, 1981.

Wahib, Ahmad Bunyan, Salafì Dáwa Movement After The Dissolution of Laskar Jihad, Yogyakarta: UIN. Accessed through google.com on 6th June 2011. 